\title{
APPLICATION OF GEOELECTRICAL PROFILING IN THE DELINEATION OF SHALLOW PERIGLACIAL STRUCTURES ON THE DROHICZYN PLATEAU
}

\author{
Radosław Mieszkowski ${ }^{1}$, Jan Dzierżek ${ }^{1}$, Dominik Stańczuk ${ }^{2}$ \\ ${ }^{1}$ Faculty of Geology, University of Warsaw, Żwirki i Wigury 93, 02-089 Warsaw, Poland; \\ e-mails:r.mieszkowski@uw.edu.pl; j.dzierzek@uw.edu.pl \\ 2 Polish Geological Institute - National Research Institute; Rakowiecka 4, 00-975 Warsaw, Poland; \\ e-mail:dominik.stanczuk@pgi.gov.pl
}

\begin{abstract}
The paper describes the results of geoelectrical sounding application for the delineation of periglacial structures in Wierzchuca Nagórna within the Drohiczyn Plateau (eastern Poland). The method records the variation of apparent resistivity of deposits along a selected horizontal direction. The survey utilizes a distinct geoelectrical contrast between glacial till and structures composed of sand that have been recognized earlier in the gravel pit wall. The studies have been conducted in direct hinterland of the gravel pit. Rectangular and concentric arrays were applied in the survey. The results have been presented as graphs and resistance distribution maps. The obtained geological image is not complete, although it shows an oriented course of the largest lineaments and traces of a network with a small mesh size $(1.5-2 \mathrm{~m})$. The recognized pattern of structures points to harsh climatic conditions during their formation. General orientation of the structures corresponds to the basic elements of the contemporary landscape in the area (slope, valley axes). Geoelectrical sounding using the rectangular array gave better results than in the concentric array, whereas introduction of brine into the system did not enhance the resolution of the readings. The presented resistance distribution maps with a characteristic rhythm of variations may serve as a benchmark for recognizing periglacial structures in areas without exposures.
\end{abstract}

Key words: eastern Poland, Pleistocene, periglacial structures, palaeogeography, geoelectrical profiling

Manuscript received 13 May 2014, accepted 5 November 2014

\section{PRINCIPLES OF GEOELECTRICAL PROFILING}

Geoelectrical profiling refers to the record of apparent resistivity variations of different lithologies along a selected horizontal direction (profile). The selected electrode spacing allows to register the magnitudes at certain depths, thus to conclude on the course of geological structures below the surface. Direct magnitudes that are measured are: the transmitted current in the supplying circuit, the potential in the measuring circuit and the dimensions of the entire measuring system (Fajklewicz, 1972; Stenzel and Szymanko, 1973). Transition from these magnitudes to apparent resistivity $r$ is expressed by the following equation:

$$
\rho=K \frac{\Delta V}{I}
$$

where $\mathrm{K}$ is the geometrical factor expressed as:

$$
K=\frac{2 \pi}{\left(\frac{1}{r_{A M}}-\frac{1}{r_{B M}}-\frac{1}{r_{A N}}+\frac{1}{r_{B N}}\right)}
$$

where: A, B - current electrodes,

$\mathrm{M}, \mathrm{N}$ - potential electrodes,

$r_{A M} ; r_{B M} ; \mathrm{r}_{\mathrm{AM}} ; r_{A N} ; r_{B M}-$ distances between the electrodes; $\mathrm{DV}$ - measured potential $[\mathrm{mV}]$;

I - transmitted current [mA].

The $\mathrm{K}$ coefficient remains unchanged during the survey, because $\mathrm{AB}$ and $\mathrm{MN}$ distances are constant. The method is particularly effective for media with highly diverse geoelectrical properties (Fig. 1). The main assets of such survey are: its non-invasive character, low cost, and relatively high resolution of the measurements. Geoelectrical profiling has been first applied to recognize the pattern of pseudomorphs after frost wedges for the SW part of the Drohiczyn Plateau (Mieszkowski and Porzeżyński, 2004, 2006). The geological 


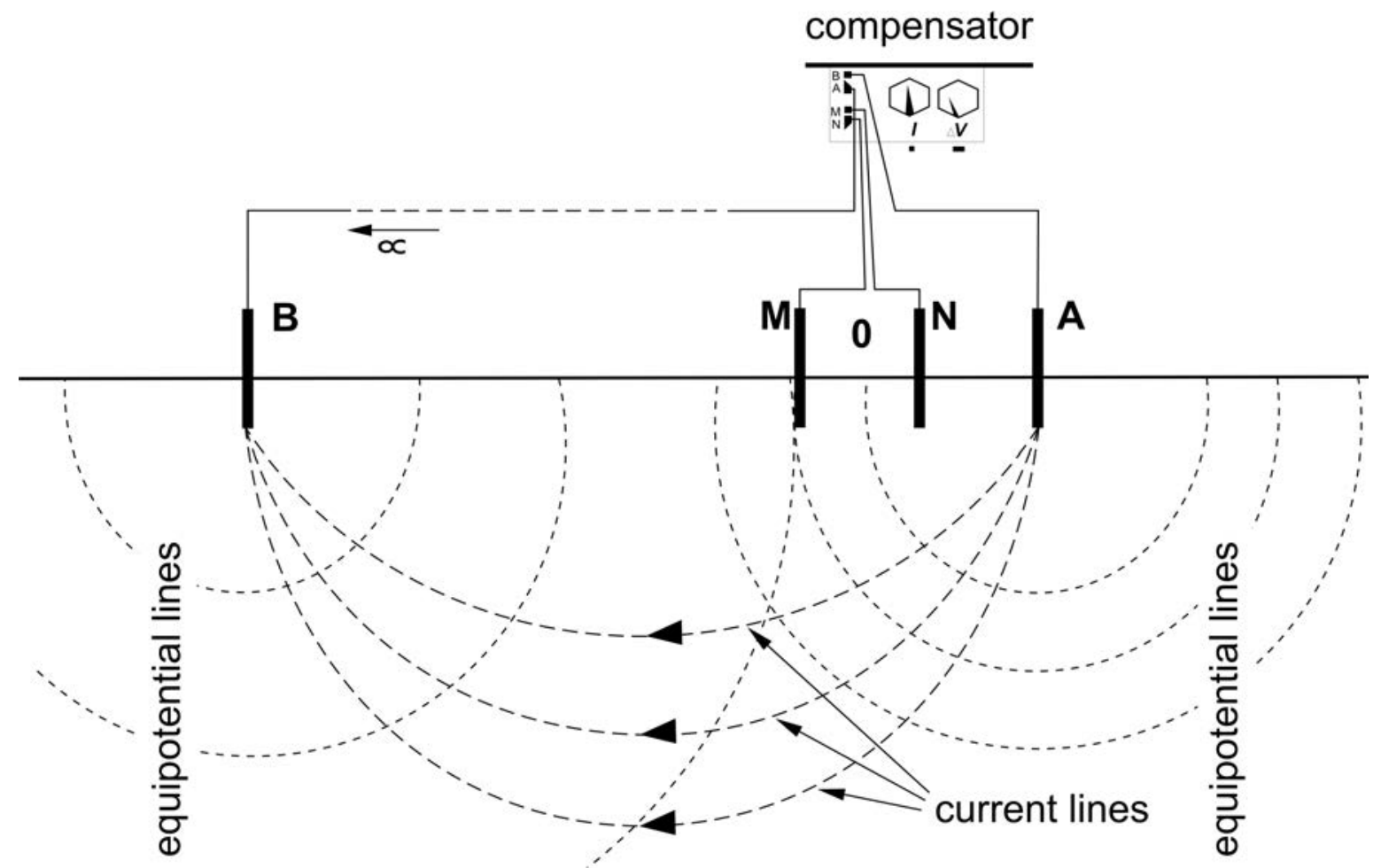

Fig. 1. Scheme of a non-symmetric measurement array.

structure of the sub-surface horizons in the area assured good conditions to test the method.

\section{GEOMORPHOLOGICAL AND GEOLOGICAL CHARACTERISTICS OF THE SW PART OF THE DROHICZYN PLATEAU}

The south-western part of the Drohiczyn Plateau is bounded by the Bug River Valley (Podlasie Bug Gorge), which in this area rapidly changes direction from WNW to NNW (Fig. 2). The levelled surface of this part of the plateau lies at $135-150 \mathrm{~m}$ a.s.l. The bottom of the Bug Valley is located at 105-110 $\mathrm{m}$ a.s.l. The erosional slope of the plateau is high and steep and is best observed in the Drohiczyn escarpment. Straight valleys with gentle slopes, running almost perpendicularly to the Bug Valley, are a characteristic element of the landscape. The dominating orientations of the valley axes are close to $\mathrm{W}-\mathrm{E}$ and NNW-SSE; this fact has been taken into account in the palaeogeographic reconstruction of the area (Dzierżek, 2009).

The main horizon in the topmost part of the geological succession in the Drohiczyn Plateau is glacial till, one to several meters thick, occasionally covered with a thin horizon of sands with gravels. The till derives from the Wartanian Glaciation (Marks, 2005; Marks and Pavlovskaja, 2004; Nitychoruk, et al. 2008a, b), at present referred to the Wartanian Stadial (Lindner and Marks, 2012). Below the till occur gravels and sands that are over $4 \mathrm{~m}$ thick (Dzierżek and Stańczuk, 2006). The geological setting of the Drohiczyn Plateau is well visible in the walls of the gravel pit at Wierzchuca Nagórna (Fig. 3). Soil is underlain by silty sands with concentrations of gravel. Between 0.3 and $0.5 \mathrm{~m}$ lies the top of brown till with a thickness of up to $1.5 \mathrm{~m}$. The till contains numerous fissures and veins filled with sand and gravel, occasionally with thin horizons of sandy mud. The sand structures terminate in the till or in the sand-gravel horizon beneath. Their formation is connected with the activity of Pleistocene frost processes within the permafrost (Dzierżek and Stańczuk, 2006). The contraction fissures were primarily filled with ice. After permafrost degradation the ice was replaced by sand and gravel, and the structures attained the form of pseudomorphs after ice wedges. Some fissures could be filled with sand already in periglacial conditions, resulting in the formation of a primary filling (Murton et al., 2000; Dzierżek and Stańczuk, 2006).

\section{GEOLOGICAL RECORD OF PERIGLACIAL STRUCTURES IN THE WIERZCHUCA NAGÓRNA GRAVEL PIT WALL}

The phenomenon of the Wierzchuca Nagórna site is the presence of at least 51 pseudomorphs after ice wedges in an over $150 \mathrm{~m}$ long gravel pit wall (Fig. 3). High density of the structures (every $1.7 \mathrm{~m}$ ) may reflect harsh climatic conditions existing during their formation (Maizels, 1986; Mackay, 1993; Barry and Gan, 2011). The pseudomorphs are generally about $1 \mathrm{~m}$ long, although shorter structures, 0.6-0.8 m long, are also present. The width of the upper parts of the pseudomorphs varies within $0.2-0.5 \mathrm{~m}$, however, in some cases it reaches even $1 \mathrm{~m}$. Some structures attain a typical wedge shape, although narrow veins and wide shafts with vertical walls have also been noted (Washburn, 1973; Jahn, 1977; French, 2007). The record of periglacial frost processes is also evidenced by: the vertical distribution of pebbles in the upper part of the glacial till, the convex top of the till between the pseudomorphs, a blurred sedimentary struc- 


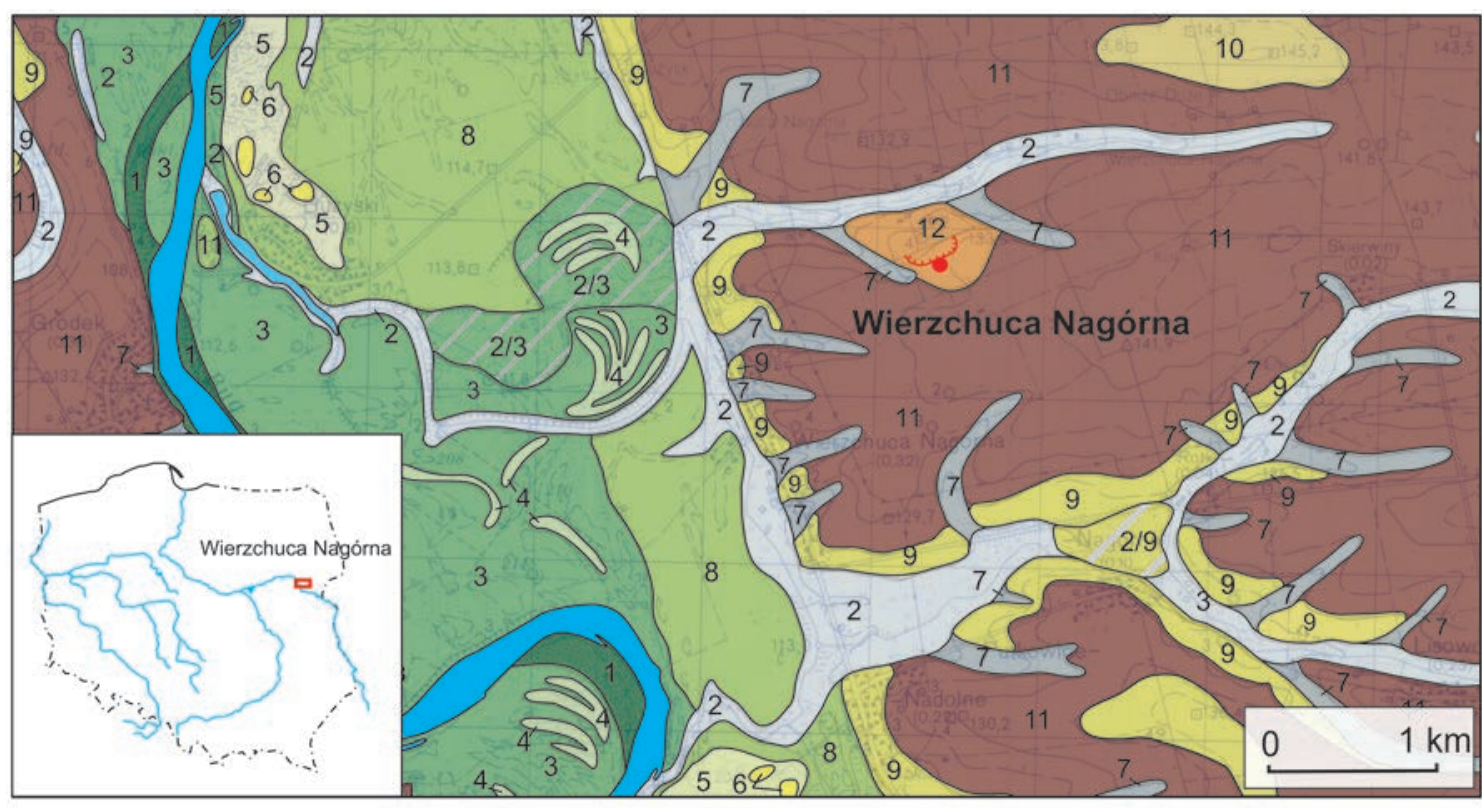

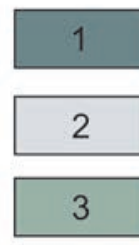

\section{4}

\section{5}

6

7 sands of point bars

humus sands and muds

sands and muds of flood terraces

sands of meander bars

aeolian sands

dune sands

deluvial sands and clays
8

9

10

11 glacial tills

12 fluvioglacial gravel and sands

gravel pit escarpment and measurement arrey

Fig. 2. Location of the study area on a geological map (Nitychoruk, et al. 2008a).

NE

ma.s.t.

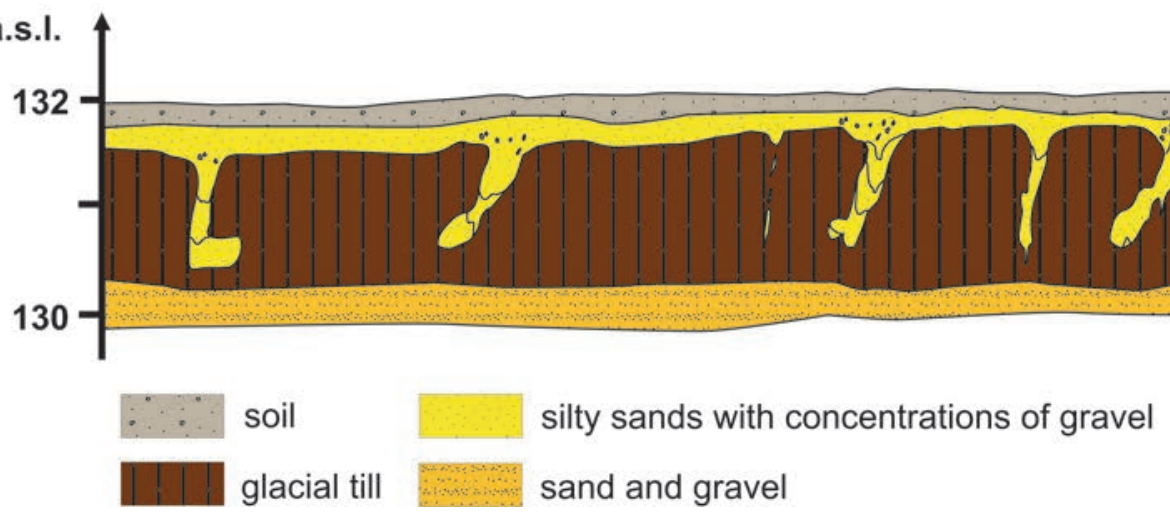

Fig. 3. Pseudomorphs after ice wedges in the gravel pit wall at Wierzchuca Nagórna (modified from Dzierżek and Stańczuk, 2006).

ture of the surface horizons and the presence of pebble concentrations (frost segregation) close to the pseudomorph top boundaries (Dzierżek and Stańczuk 2006).

Shapes of the pseudomorphs and their distribution in the gravel pit wall point to a polygonal network developed on the plateau top. Reconstruction of its character, including: shapes of the polygons, mesh size, network generations and privileged fissure orientations, is of palaeogeographic significance. It allows concluding not only on the properties of past climate, but also, for example, on the existence of natural 


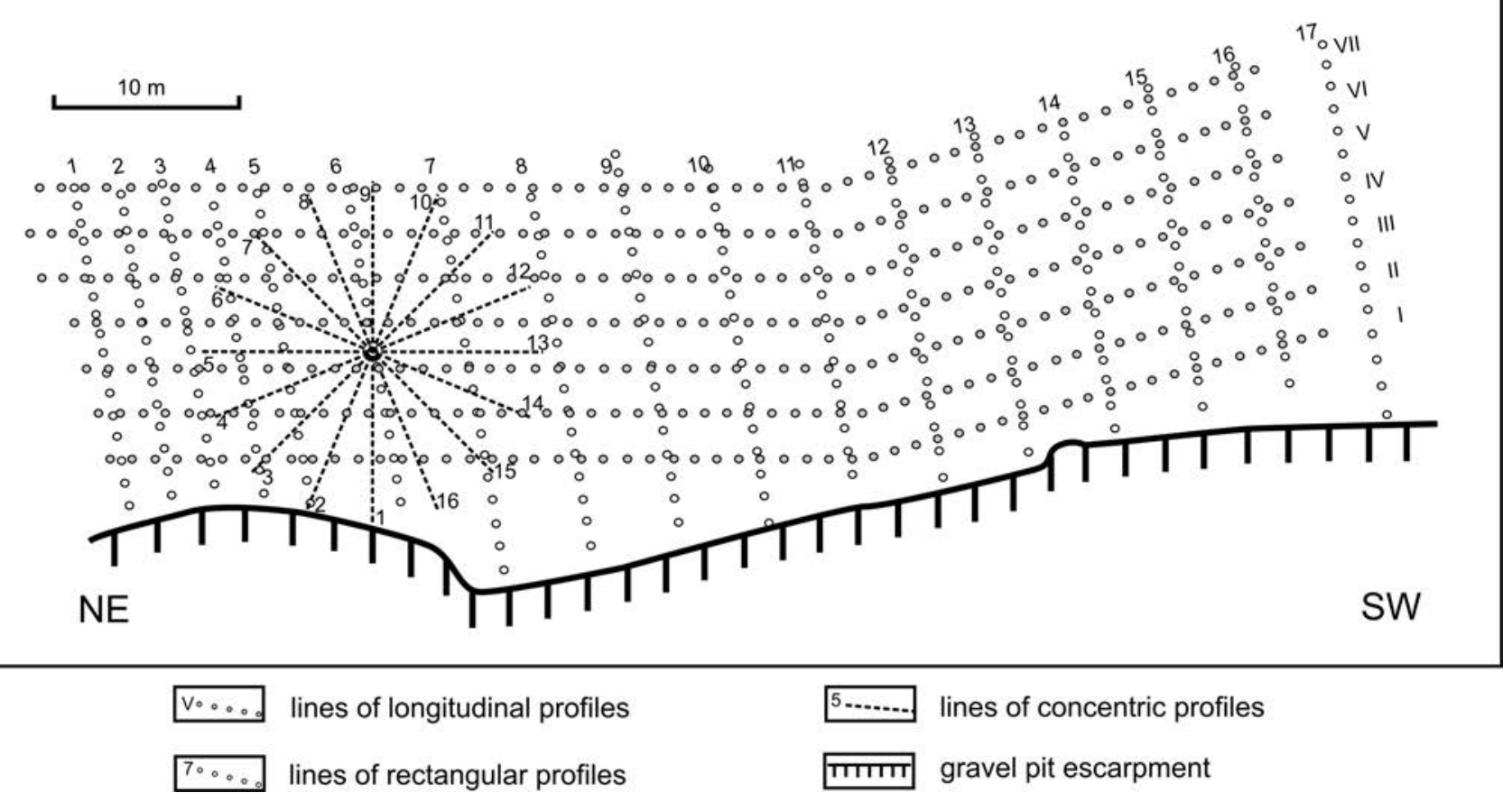

Fig. 4. Distribution of lines of geoelectrical sounding in a rectangular array and concentric array.

morphological or geological escarpments. Typically, such escarpments are recorded by the privileged orientation of the contraction fissures in the soil (the main generation of the fissures), to which the smaller fissures are adjusted (Jahn, 1970, 1977; French, 2007). Similar cases can be observed in contemporary periglacial areas. Analysis of the pioneering application of geoelectrical sounding is presented below with the use of earlier palaeogeographic analysis (Dzierżek, 2009).

\section{RESULTS OF GEOELECTRICAL STUDIES IN A RECTANGULAR ARRAY AND THEIR INTERPRETATION}

In the survey area described above, the top of the till is in distinct geoelectrical contrast with regard to the infilling sediments. The resistivity of till is at $30-80 \Omega \mathrm{m}$, whereas that of sand and gravel exceeds $150 \Omega \mathrm{m}$. This complex is covered by a thin $(0.6-0.8 \mathrm{~m})$ layer of silty sands with gravel admixture; it has an identical influence on the measurements and thus may be omitted in the interpretations. Such conditions theoretically allow for the recognition of the horizontal occurrence of tills and sands in the pseudomorphs directly below the surface.

At first, a rectangular array, non-symmetric with infinity, was applied (Mieszkowski and Porzeżyński 2004). The spacing of the electrodes supplying A0 was $1 \mathrm{~m}$, with the second supplying electrode (B) located at a significant distance from the survey profile (Fig. 1). The measuring electrodes M0 and N0 were spaced at $0.3 \mathrm{~m}$. The spacing was $1 \mathrm{~m}$ for both the longitudinal and transverse profiles. Advantages of this array include the engagement of a lower number of employees ( 3 persons) and a short survey time. Measurements were conducted along 7 longitudinal profiles and 17 transverse profiles (Fig. 4). The first longitudinal profile was loca- lized at several meters from the gravel pit escarpment. Fiftyseven shallow geological drillings were made along the line of the first longitudinal profile. Additionally, several controlling drillings were made within the rectangular array. This allowed correlating the geoelectrical interpretation with the lithology, and due to the close vicinity of the wall - interpretation of the orientation of structures visible in the exposure. The calculated resistivity values are presented in charts, where horizontal coordinates refer to the localization of the measurement points and vertical coordinates represent the measured values of apparent resistivity corresponding to the centre of system 0 . Intersection of points in the coordinate system forms the lines of the resistivity profiles (Fig. 5).

A series of controlling manual drillings have been made on the flat surface in the hinterland of the gravel pit escarpment. Correlation of the apparent resistivity measurements with the lithological sections obtained from the drillings indicate: 1) increased apparent resistivity when sands and gravels were drilled; and 2) decreased apparent resistivity in the case of till. This knowledge was applied in the interpretation of the remaining profiles. Distinct positive peaks in the charts (Fig. 5) can be combined with the presence of increased thicknesses of sands (over $1 \mathrm{~m}$ ) or thin horizons of gravels (about a dozen $\mathrm{cm}$ ) in the site. The presence of an over 50 $\mathrm{cm}$-thick horizon of sands and a few cm-thick horizon of gravel should also not be excluded. However, for the assumed goal this fact does not cause significant differences, because in both cases it points to the occurrence of a sandgravel pseudomorph in the glacial till. The presence of sections with lower apparent resistivity values in the survey profiles can be interpreted as the shallowly lying top of glacial till (i.e. area without pseudomorphs). However, the shape of the charts does not depend only on the properties of the surveyed medium. Apparent resistivity values measured along 

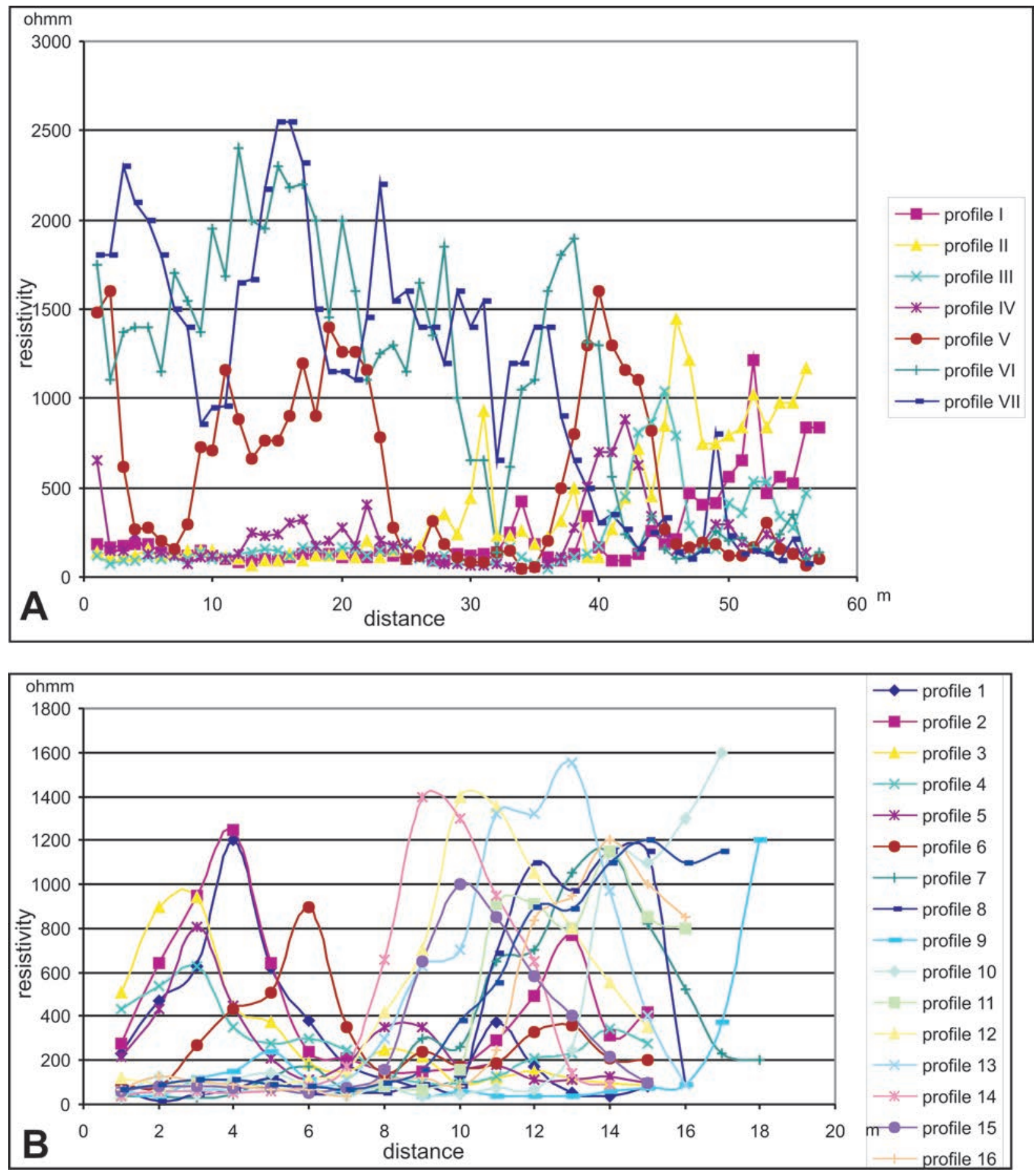

Fig. 5. Distribution of apparent resistivity along longitudinal (A) and transverse (B) profiles (Mieszkowski and Porzeżyński, 2004).

profile I are distinctly lower in relation to the other measurements (even by 50\%). This probably results from the disturbance in the measurement system caused by the nearby gravel pit wall. "Thinning" of the electric current lines takes place in the hinterland of the gravel pit escarpment, i.e. measurement by compensator gives decreased values of DV (which is numerator in the equation presented above), and thus lower apparent resistivity values. It could also be noted that the application of a non-symmetric array, i.e. electrode B moving to infinity, has caused the translocation of the system centre " 0 " by several tens of centimetres. Shallow manual drillings have allowed to state that this translocation was commonly at $30 \mathrm{~cm}$ towards electrode A with regard to the system centre " 0 ".

Presentation of the survey measurements in the charts has allowed observing and explaining anomalies in the first course of measurements. However, due to the alleged goal of the survey, such presentation of apparent resistivity variation in the sub-surface part of the study area is not sufficient. It is difficult to correlate with the surface arrangement of resistiv- 

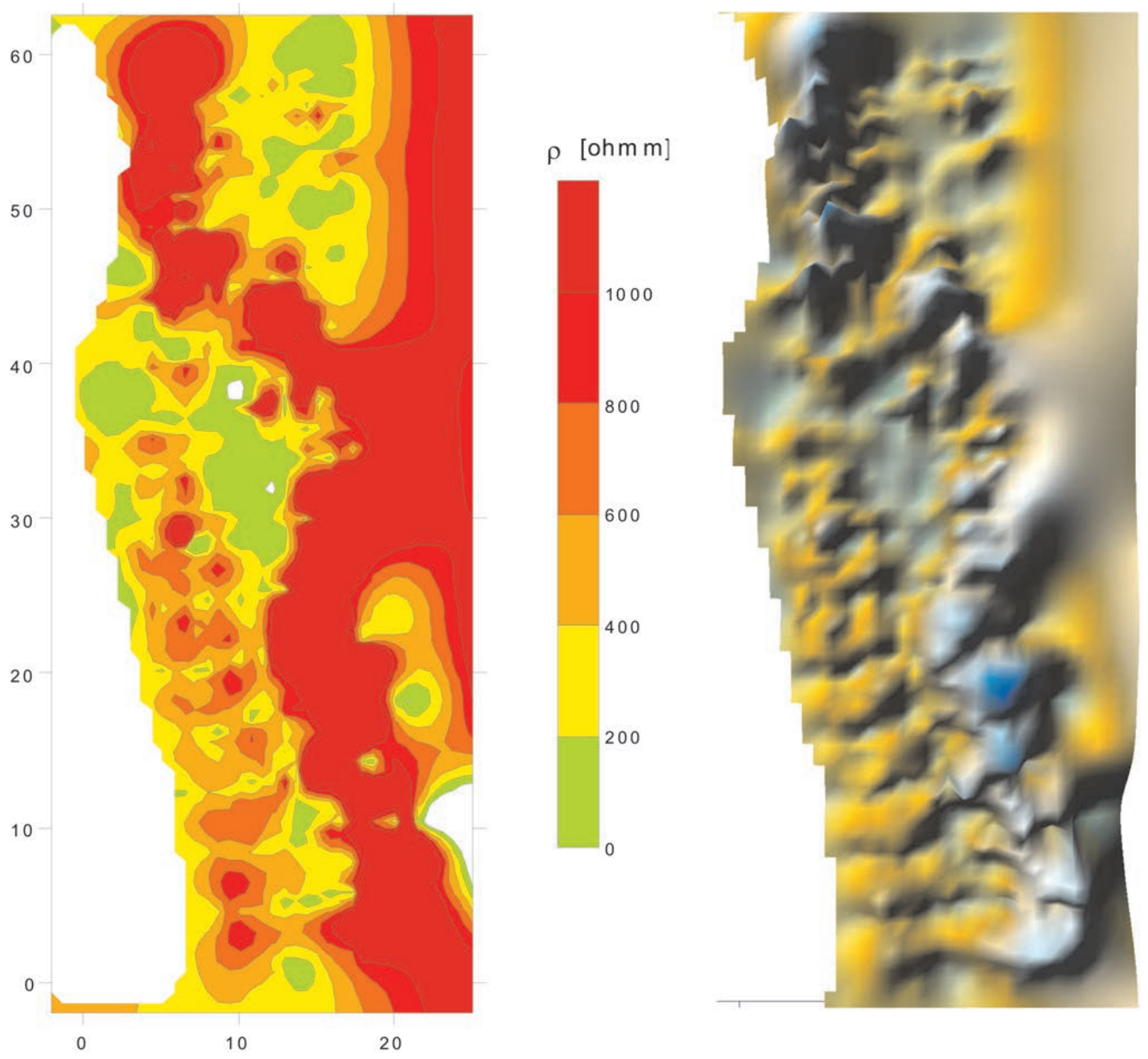

Fig. 6. Maps of apparent resistivity distribution in a rectangular array in 2D (left) and 3D (right) (modified from Mieszkowski and Porzeżyński, 2004).

ity variability. Therefore, the results are presented in a plan within a measuring grid as 2D maps of resistivity variation (Fig. 6). According to the arguments pointed out above, the influence of the gravel pit escarpment has been included by multiplying the values of apparent resistivity in longitudinal profile I by coefficient 2, in longitudinal profile VII by 1 , and subsequently for all the profiles (from II to VI) by relevant coefficients 1 or 2 . The red fields indicate the presence of soils with higher apparent resistivity, i.e. sands and gravel. Fields marked yellow and green refer to clays (till) with lower resistivities. The map shows that some red fields are distinctly elongated, which may be interpreted as the probable course of the sand structures. The image is not complete, but shows the orientation of the largest lineaments and traces of a network with small mesh sizes. The presence of wide bands of high resistivity values in the upper left on the map of the study area may result from the geological setting or from errors in data interpolation in the terminal part of the survey profile. In turn, the several meters-broad high resistivity band with irregular margins in the lower left on the map of the study area probably reflects the orientation of the broad sand infilling. Such interpretation is confirmed by observations in the south-western part of the gravel pit wall, where an over 1-m wide "ditch" filled with sand is visible in the till (see Fig. 3).

Results of the resistivity survey have also been presented in a 3D map (Fig. 6). In the case of search for a system of shallow sand infillings within the till, this method of presenting the results seems the most favourable. The vivid picture almost instantaneously reveals not only the orientation of the main axes of resistivity variation (and thus also lithology), but also their depth. At certain light directions, places with higher resistivity gather on the 3D map in longitudinal struc- 

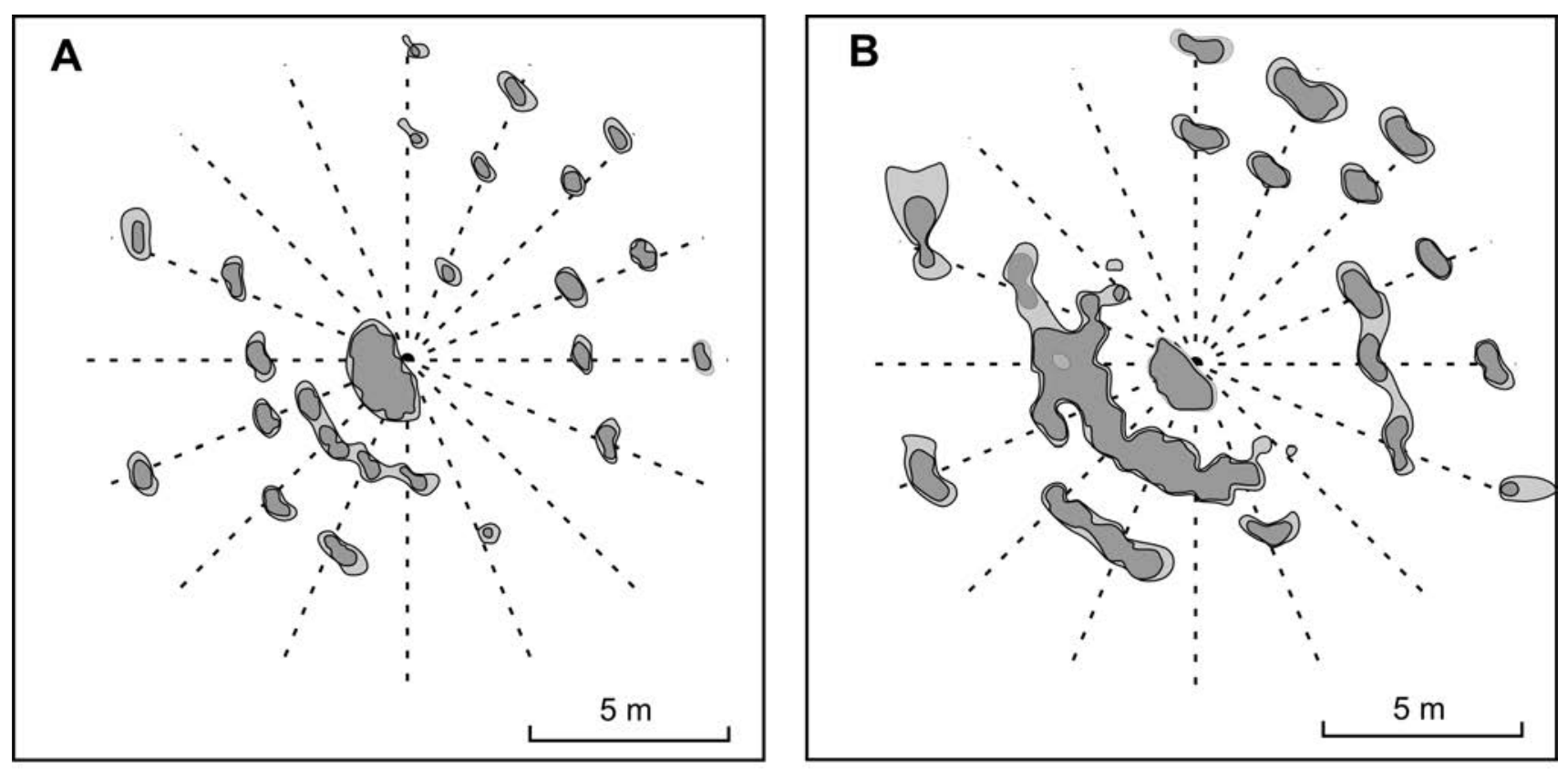

resistance: $30-80 \Omega \mathrm{m}$ $81-100 \Omega \mathrm{m}$ $>100 \Omega \mathrm{m} ; 0$ lines of sounding

Fig. 7. Maps of apparent resistivity distribution in a concentric array (A), and $24 \mathrm{~h}$ after brine application (B) (modified from Mieszkowski and Porzeżyński, 2004).

tures with a distinct "crest line". These lines have been correlated with relevant peaks on the working charts, which allowed determining the axes of the sand structures. The structural axes on the plan have been correlated with the structures visible in the escarpment of the gravel pit. As a result, the orientation of the main axes was determined, although the fissure system seems incomplete. The main axes of the reconstructed ice wedges (NW-SE) are oblique to the structural lines and correspond to the dominating slope dip in the area. This may suggest that during the frost processes, the surface of this part of the plateau attained a certain dip (Dzierżek and Stańczuk, 2006; Dzierżek, 2009).

However, comparison of the obtained sketch of the structure system with examples of frost fissure systems in recent periglacial areas, shows that the polygons were not closed and there was a lack of minor fissures between the main fissures. In order to obtain a precise image, the same area was again subject to a geoelectrical survey, in this case in a pole-pole concentric array.

\section{RESULTS OF GEOELECTRICAL SURVEY IN A CONCENTRIC ARRAY AND THEIR INTERPRETATION}

The concentric array comprised one electrode situated in the circle centre, with the second electrode repositioned every $0.5 \mathrm{~m}$ along sixteen radiuses, each $8 \mathrm{~m}$ long. The attained density of the measurement lines (angle value and radius length) seemed sufficient at the expected fissure density. In this case, the survey was focused on checking and eventually increasing of the density of the obtained image within a small area, followed by extrapolation of the obtained system on the area in the hinterland of the escarpment.

The obtained image distinctly points to the presence of narrow zones with high resistivity $(>150 \Omega \mathrm{m})$, corresponding to sands and gravel, within low resistivities corresponding to till (Fig. 7A). Lines connecting the maxima are of various length, and in some places have been interpolated between the particular profiles. Despite that, a NW-SE orientation of the most distinct elongated fields can be seen. Outlines of sections that are transverse and oblique to the main lines and intersections of orientation variation of resistivity distribution can be recognized.

The image of sand structures obtained from resistivity measurements in the concentric array was superimposed on the structural lines delineated in the rectangular array (Fig. 8). High correlation of the structure orientation has been obtained. Some sections conform with one another, others represent extensions of the earlier ones, and some short sand structures have been registered in either of the arrays.

Additionally, two series of geoelectrical measurements have been conducted with brine introduced into the system. The idea was based on two main assumptions: 1) the brine will enhance the contrast (and resolution of the readings) between the resistivity in sands within the pseudomorphs and their till surroundings; 2) the solution will disperse within the sands. Thus, it would be possible to detect the resistivity changes along the migration routes, i.e. orientation of the sand pseudomorphs. In the centre of the concentric array, within the sand infilling of the pseudomorph, a hole was dug, in which 801 of $10 \%$ brine solution were introduced. Resistivity measurements in the concentric array with application 


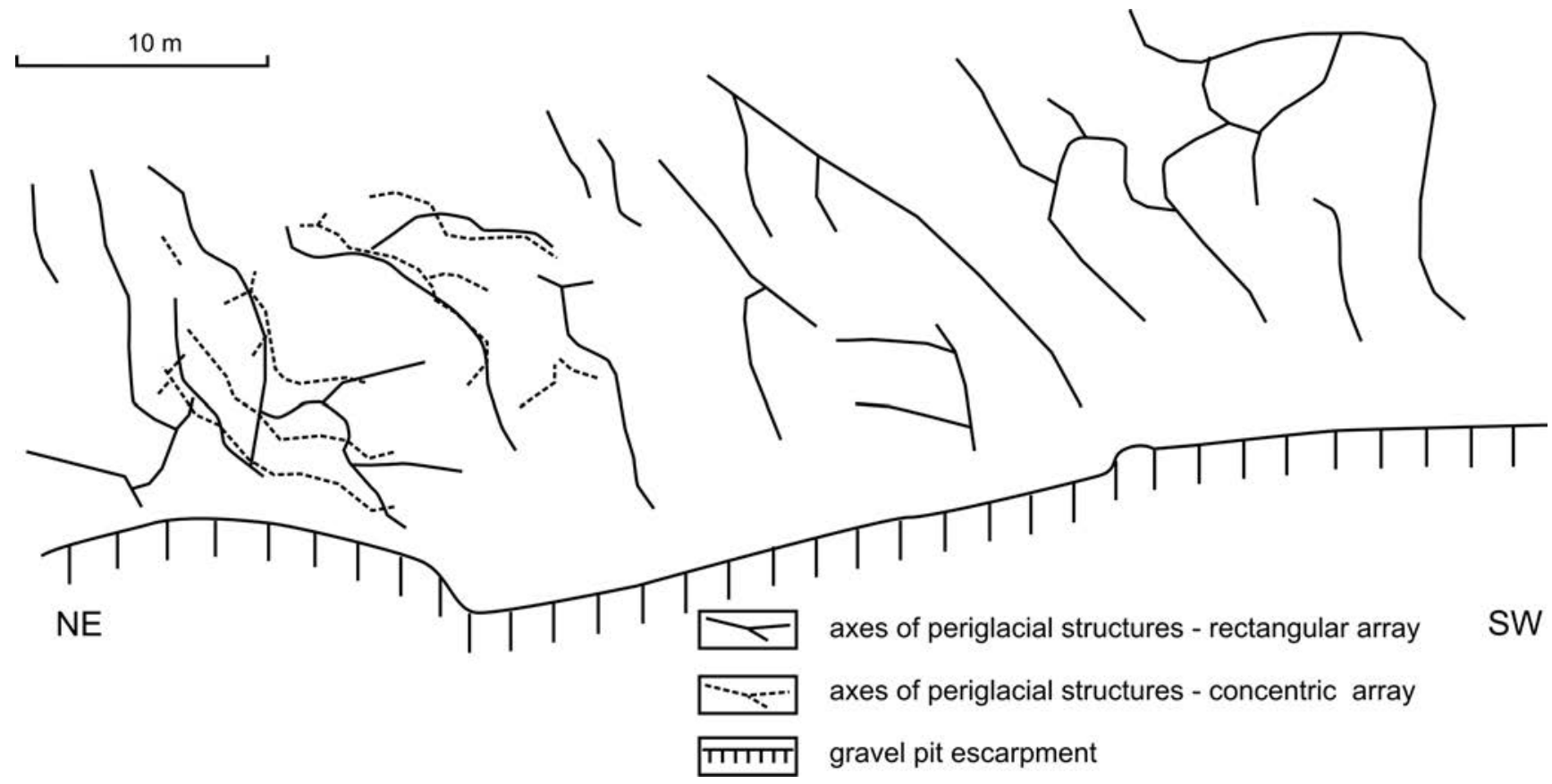

Fig. 8. Distribution of periglacial structures in the hinterland of the gravel pit escarpment at Wierzchuca Nagórna recognized by geological sounding (modified from Mieszkowski and Porzeżyński 2004)

of brine were conducted one hour after the application and repeated after 24 hours.

Maps showing the results of subsequent resistivity measurements in the concentric array have shown certain variability. The chart with resistivity measured 1 hour after brine introduction shows a wide field of high resitivities close to the centre and numerous small dispersed fields, which rather distinctly indicate linear variability of the resistivity values. Clearer and located closer to the centre are structures in the SW part of the system. The image for the situation after $24 \mathrm{~h}$ of brine application is more variable; fields with higher resistivity values are larger and in some places connected to form more distinct linear structures (Fig. 7B).

Images from the three series of measurements, despite some differences, conform the outlines of the main structures. However, the results of the surveys did not fulfil the expectations. Resistivity changes are not completely unambiguous. Brine migration routes have turned out to be unclear and peter out, and the image after brine application is not significantly different from the image without brine (see Fig. 7A and B). The technical reason for such image could be the insufficient amount of solution in the system. Introduction of considerable amounts of the solution would result in a significant environmental impact. Another reason could be the geological setting of the study area. The gravel pit wall shows that some fissures with sand infillings reach below the base of the impermeable till (Fig. 3). Thus, the brine solution could escape inwards, directly to the gravel horizon underlying the till. Even if the system was sealed from the bottom, the angle and dip orientation of the entire system remain unknown, whereas these are the factors determining the favoured migration routes of the brine.

\section{ASSESSMENT OF THE USEFULNESS OF GEOELECTRICAL SOUNDING FOR THE RECONSTRUCTION OF SHALLOW PERIGLACIAL STRUCTURES}

The presented discussion of the results obtained from geoelectrical measurements in the study area at Wierzchuca Nagórna in the Drohiczyn Plateau provides several conclusions on assessing the usefulness of the method in the recognition of a frost fissure network. In general, geoelectrical profiling does not deliver a detailed image of the surface system of periglacial structures. However, when its results are correlated with a well-recognized geological setting, the margin for the interpretation of the results of geoelectrical sounding clearly narrows. The results have shown distinct and frequent resistivity variation in a small area as well as the presence of larger zones with higher resistivity. Although the reconstructed network is not complete, it allowed to conclude on the palaeogeomorphology. In a few cases, narrow high resistivity zones distinctly record fragments of the network mesh (polygons), providing information on their size and density. The network of pseudomorphs is irregular and the smaller structures contact at right angles with the main structures.

It seems that geoelectrical profiling using a rectangular array gives better results; their presentation in resistivity variation maps, particularly in $3 \mathrm{D}$, allows for a geological interpretation. Attempts to enhance the signal by introduction of brine and to obtain an image of better resolution have turned out to be ineffective. Moreover, larger labour input and a significantly high invasiveness of the method does not permit its recommendation for such surveys. The obtained 
maps of resistivity distribution with a characteristic rhythm of numerous variations may exemplify the geoelectrical record of periglacial structures and can be used to compare the results of such studies in areas without exposures. It seems that the hinterland of the escarpment of the Wierchuca Nagórna exposure in the Drohiczyn Plateau is a perfect benchmark for testing other geophysical methods, e.g. georadar surveys and electrical resistivity tomography.

\section{CONCLUSIONS}

Experience gained during geoelectrical surveys in the Drohiczyn Plateau near Wierzchuca Nagórna can be assembled in several conclusions.

- High-resolution geoelectrical profiling has confirmed the presence of numerous periglacial structures, observed in the nearby exposure, and enabled a partial reconstruction of their surface pattern.

- Periglacial structures are manifested in the map of soil resistivity distribution as narrow elongated fields with high resistivities (sand with gravel) in a low resistivity background (till).

- Tthe structures are NW-SE-oriented and have a small diameter of single fissure polygons; these data have been applied in palaeogeographic reconstructions (Dzierżek, 2009).

- Measurements in a rectangular array have given better results. They are less time-consuming, non-invasive, have covered a larger area and the results are easier to interpret.

- Rresults obtained for the marginal profiles of the rectangular array are unreliable and may be considered only after relevant corrections.

- Attempt to enhance the contrast of the readings by introduction of brine in the system has been proved ineffective, although it supplied new possibilities of interpreting the sub-surface geological structure of the area.

- Correlation of the results of geoelectrical surveys to the geological succession has facilitated their interpretation. The obtained resistivity distribution map may serve as comparative material in the identification of periglacial structures with application of geoelectrical sounding in areas without exposures.

- Verification of the obtained results could be achieved by conducting other geophysical surveys in the area.

\section{REFERENCES}

Barry, R., Gan, T. Y., 2011. The global Cryosphere: past, present, and future., Cambridge University Press, ss. 472, New York.

Dzierżek. J., 2009. Palaeogeography of selected areas in Poland during the Last Glaciation. Acta Geogr. Lodz., 95, ss. 112. (in Polish with English summary)

Dzierżek, J., Stańczuk, D., 2006. Record and palaeogeographic implications of Pleistocene periglacial processes in the Drohiczyn Plateau, Podlasie Lowland. Geol. Quart., 50 (2), 219-228.

Fajklewicz, Z., (ed.), 1972. Outline of practice geophysics (Zarys geofizyki stosowanej). Wyd. Geol., ss. 923. (in Polish)

French, H., 2007. The periglacial environments. $3^{\text {rd }}$ ed., ss. 458, New York, Wiley.

Jahn, A., 1970. The problem of periglacial zone. (Zagadnienia strefy peryglacjalnej. PWN, ss. 202, Warszawa. (in Polish)

Jahn, A., 1977. Structures connected with ice wedges in Pleistocene deposits. Studia Geologica Polonica, 52, 177-194.
Lindner, L., Marks, L., 2012. On the climatostratigraphic scheme of the Middle Polish complex in the Pleistocene of Poland. Prz. Geol., 60, 36-45. (in polish with English summary)

Mackay, J.R., 1993. Air temperature, snow cover, creep of frozen ground, and the time of ice-wedge cracking, western Arctic coast. Canad. J. Earth Sci., 30, 1720-1729.

Maizels, J. K., 1986. Frequency of relic frost-fissure structures and prediction of polygon pattern. A quantitative approach. Biul. Perygl., 30, 67-89.

Marks, L., Pavlovskaya, I. 2004. Extens of Pleistocene glaciations in Eastern Poland and Western Belarus (Zasięgi zlodowaceń plejstoceńskich na obszarze Wschodniej Polski i Zachodniej Białorusi). Mat. XI Konferencja Stratygrafia Plejstocenu Polski, Supraśl, 8-10. (in Polish)

Marks, L., 2005. Pleistocene glacial limits in the territory of Poland. Prz. Geol., 53 (10/2), 988-993.

Mieszkowski, R., Porzeżyński, S., 2004. Report on the results of geoelectrical survey in the region of Drohiczyn. (Opracowanie wyników badań geoelektrycznych w rejonie Drohiczyna). Arch. Inst. Geol. Podst. Uniw. Warsz., ss. 6. (in Polish)

Mieszkowski, R., Porzeżyński, S., 2006. Report on the results of geoelectrical survey in the region of Drohiczyn. Part II. (Opracowanie wyników badań geoelektrycznych w rejonie Drohiczyna. Cz. II.), ss. 8. (in Polish)

Murton, J., Worsley, B., Goździk, J., 2000. Sand veins and wedges in cold Aeolian environments. Quatern. Sci. Rev., 19, 899-922.

Nitychoruk, J., Dzierżek, J. Stańczuk, D., 2008a. Detailed Geological Map of Poland in the scale 1: 50 000; Drohiczyn Sheet. (Szczegółowa mapa geologiczna Polski w skali 1: 50000 ark. Drohiczyn - 494). Państw. Inst. Geol. (in Polish - electronical document)

Nitychoruk, J., Dzierżek, J. Stańczuk, D., 2008b. Explanations to the Detailed Geological Map of Poland in the scale 1: 50 000; Drohiczyn Sheet. (Objaśnienia do Szczegółowe mapy geologicznej Polski w skali 1 : 50000 ark. Drohiczyn - 494). Państw. Inst. Geol., ss. 53 (in Polish - electronical document)

Stenzel, P., Szymanko, J., 1973. Geophysical methods in hydrogeological and geological-engineering studies. (Metody geofizyczne w badaniach hydrogeologicznych i geologiczno inżynierskich). Wyd. Geol. Warszawa.

Washburn, A., 1973. Periglacial processes and environments. Edward Arnold. London. 